\title{
Urbanicity mental costs valuation: a review and urban-societal planning consideration
}

\author{
Luca S. D'Acci ${ }^{1}$
}

Received: 21 January 2020 / Accepted: 6 June 2020 / Published online: 30 June 2020

(c) Springer-Verlag GmbH Germany, part of Springer Nature 2020

\begin{abstract}
Living in cities has numerous comparative advantages than living in the countryside or in small villages and towns, most notably better access to education, services and jobs. However, it is also associated with a roughly twofold increase in some mental disorders rate incidence compared with living in rural areas. Economic assessments reported a forecasted loss of more than 19 trillion dollars in global GDP between 2011 and 2030 and of around 7 trillion for the year 2030 alone when measured by the human capital method. If we exclude self-selection processes and make the hypothesis to be able to level down the mental illness rate incidence in urban areas to these of the rural by better urban-societal planning, around $€ 1.2$ trillion could be saved yearly worldwide. Even a reduction of only $20 \%$ in urban mental illness rate would save around 250 billion dollars yearly.
\end{abstract}

Keywords Urban quality of life · Urbanization · Psychology of urban life · Economic valuations $\cdot$ Neurourbanism

\section{Introduction: urbanicity, mental health, life satisfaction, and residential preferences}

Within the top twenty reasons of global burden of disease, there are five mental illness - depression (2nd), anxiety (7th), schizophrenia (11th), dysthymia (16th), and bipolar disorder (17th) — which in 2013, even if probably underestimated by more than $1 / 3$, resulted to be the leading causes of years lived with disability (Vigo et al. 2016). Globally, in 2015, non-communicable diseases were $60 \%$ of total disabilityadjusted life-years, of which $12 \%$ corresponded to mental disorders, neurological disorders, substance use disorders, and self-harm (Vigo et al. 2019); mental health

Luca S. D'Acci

luca.dacci@polito.it

1 Interuniversity Department of Regional and Urban Studies and Planning, Politecnico di Torino, Castle of Valentino, Viale Mattioli, 39, 10125 Turin, Italy 
disorders are also the primary cause of Disability-Adjusted Life Years worldwide (Bloom et al. 2012).

Decades of empirical research shows an association between mental health and urbanicity, especially for the individuals genetically more inclined and those who lived in cities during their early life.

Links, often proven to be causal by longitudinal and dose-response analysis, between urbanicity and mental illness have been greatly reported such as in these 89 studies: Coid et al. 2020; Evans et al. 2020; Vargas et al. 2020; Sampson et al. 2020; Lecic-Tosevski 2019; Reed et al. 2018; Evans et al. 2018; Castillejos et al. 2018; Kirkbride et al. 2006, 2018; Cooper et al. 2017; Besteher et al. 2017; Gruebner et al. 2017; Krzywicka and Byrka 2017; Vassos et al. 2016; Newbury et al. 2016; Brockmeyer and D'Angiulli 2016; Adli et al. 2016; Freeman et al. 2015, Wilker et al. 2015; Peterson et al. 2015; Haddad et al. 2015; Vaessen et al. 2015; Steinheuser et al. 2014; Haluza et al. 2014; Krabbendam et al. 2014; Streit et al. 2014; CalderónGarcidueñas et al. 2013; Heinz et al. 2013; Bedrosian and Nelson 2013; Stevens et al. 2013; Tandon et al. 2012; Lederbogen et al. 2011; Fonken et al. 2011; Larson et al. 2011; Galea et al. 2011; McClung 2007, 2011; Meyer-Lindenberg 2010; Park et al. 2010; Bowler et al. 2010; Kelly et al. 2010; Mortensen et al. 2010; Levesque et al. 2011; Gwang-Won et al. 2010; Tae-Hoon et al. 2010; Peen et al. 2007, 2010; van Os et al. 2010; Kennedy et al. 2009; Bentall et al. 2008; March et al. 2008; Joens-Matre et al. 2008; Fuller et al. 2007; Graziano and Cooke 2006; Maas et al. 2006; Pedersen and Mortensen 2001a, b, 2006a, b; Weich et al. 2006; Krabbendam and van Os 2005; Tsunetsugu and Miyazaki 2005; Wang 2004; Sundquist et al. 2004; van Os 2004; van Os et al. 2004; McGrath et al. 2004; Harrison et al. 2003; Caspi et al. 2003; Frumkin 2001; Allardyce et al. 2001; Haukka et al. 2001; Torrey et al. 2001; van Os et al. 2001; Eaton et al. 2000; Schelin et al. 2000; Marcelis et al. 1999; Mortensen et al. 1999; Marcelis et al. 1998; Thornicroft et al. 1993; Lewis et al. 1992; Cohen 1982; Eaton 1974; Christmas 1973; Faris and Dunham 1939; White 1903.

Paykel et al. (2000), analysing data from almost ten thousand individuals (Household Survey of the National Morbidity Survey of Great Britain) via a logistic regression, reported "a considerable British urban-rural differences in mental health, which may largely be attributable to more adverse urban social environments".

According to Vassos et al. (2016), the rate of incidence of nine types of psychiatric disorders is in average 1.6 times higher in the capital city than in the rural areas, with 'schizophrenia and related disorders' even almost double (1.83), while the review of McGrath et al. (2004) of 68 studies found a schizophrenia incidence rate 2 times higher in urban areas than in mixed rural/urban areas; a rate that rises up to a 2.75 times greater risk of schizophrenia when one has lived 15 years of her early life in a capital city rather than a rural area (Pedersen and Mortensen 2001a). Peen et al. (2007) reported an odds-ratio for mental disorders in very highly urbanized areas of 1.6 related to non-urbanized (1.8 when unadjusted by control variables). An approximatively twofold increase in psychosis risk associated with urbanicity is also confirmed in the following empirical studies: Marcelis et al. (1998, 1999), Mortensen et al. (1999), Schelin et al. (2000), Allardyce et al. (2001), Pedersen and Mortensen (2001a, b), van Os et al. (2001, 2004), Harrison et al. (2003), Sundquist 
et al. (2004), Pedersen and Mortensen (2006a, b), Kirkbride et al. (2006), Haukka et al. (2001) and Torrey et al. (2001). An increase as high as fourfold was found in Eaton et al. (2000). A meta-analysis review summarised that urban dwellers have a 1.4 times greater risk of mood disorders than non-urban (Peen et al. 2010).

Due to the type of the analysis conducted, the causality (rather than a reverse causation) of the nature of this link, emphasising that urbanicity has an etiological effect on mental health, has been underlined, among many, by March et al. (2008), van Os et al. (2010) and Lederbogen et al. (2011).

If we shift our attention to people's preferences toward places to live their lives, "many surveys about quality of life in cities invariably suggest that it is in smaller cities that the highest quality of life is achieved" (Batty 2018, p. 95). Similarly, to European surveys, $44 \%$ of Americans voted small towns/rural environments as the best kind of places to live and only roughly one in five $(20 \%)$ voted cities (Knox and Pinch 2006). Another questionnaire (D'Acci 2020) reported that only $32 \%$ of respondents prefers to live in a city rather than (ceteris paribus) in a natural environment $(36 \%)$, in a town/village $(24 \%)$, in a suburb $(6 \%)$, while $2 \%$ of them were indifferent.

In line with these stated residential preferences, happiness seems to decrease when urbanicity levels increase (Sander 2011; Lawless and Lucas 2010), and studies about self-declared life satisfaction, psychological well-being in rich countries systematically show lower levels of life satisfaction in urban areas compared to the rural or less urban areas (Viganò et al. 2019; Easterlin et al. 2011; Gilbert et al. 2016; Helliwell et al. 2018; Fassio et al. 2013; Lawless and Lucas 2010; OkuliczKozaryn and Mazelis 2018; Okulicz-Kozaryn 2017; Sørensen 2014; Berry and Okulicz-Kozaryn 2013, 2009).

This discrepancy between rural and urban environments' influence on mental health, life satisfaction and happiness suggest that by re-organizing our socioeconomic urban daily life and the physical urban-regional structure itself, there would be a potential margin of reduction in the urban mental illness rates and an increase of life satisfaction and daily mood of urban dwellers.

To convince governments, urban and regional planners, stakeholders and the ordinary population about the relevance of the issue, an economic translation of the costs that psychological effects that cities have to us, might help to make the topic more tangible.

\section{Economic valuations of mental costs}

Mental disorder costs go far beyond the direct costs (diagnostic and treatment); their economic costs assessment for the society as a whole should monetarily translate also the following indirect factors: increased chance of leaving school early, lower likelihood of achieving good and full-time employment, reduced quality of life for the individual and her loved ones. The monetary quantification of indirect costs on health usually follows the human capital method which measures the personal direct costs plus the amount of discounted earnings from lost productivity due to 
several reasons such as those listed above (Doran and Kinchin 2017; Gustavsson et al. 2011).

Early commencement mental disorders result to be statistically significantly associated with the interruption of secondary education (Leach and Butterworth 2012), which in turn means less likelihood to be employed in higher skilled professions (Schofield et al. 2011).

As expected, psychiatric disorders between the ages of 18 and 25, after controlling for confounding variables, was statistically significantly ( $p$ value $<0.05$ ) negatively linked with workforce participation, income and economic living standards at age 30, and, more generally, cumulative episodes of psychiatric disorders negatively affect life outcomes (Gibb et al. 2010).

However, a bi-directional causality might appear between mental health and labour force participations as once workforce participation is being affected, a dangerous positive feedback loop could start: you get mentally ill then you work less, and the more excluded from work the more mentally ill you might be (Laplagne et al. 2007). This unemployment rate within the mentally ill population has being quantified to be as high as four times more than the healthy population, and when they work they are more inclined both to presenteeism (work with low productivity) and absenteeism (more leave for illness) (Schofield et al. 2011). This psychological distress cost related to lower productivity has been estimated in 2010 to be A\$5.9 billion (equivalent to roughly A $\$ 7.5$ billion in 2019) per annum in Australia (Hilton et al. 2010), and the individuals' loss due to depression has been assessed as a $73 \%$ lower income than their full-time counterparts, while those deciding to retire early because of their mental health issues have $78 \%$ lower incomes, which at a national aggregate level means US\$ 407 million in transfer payments, \$ 278 million in lost income taxation revenue, and almost \$ 2 billion in GDB, just in 2009 (Schofield et al. 2011).

Reports for Canada (Smetanin et al. 2011) assessed that in 30 years (2011-2041) the cumulative costs related to mental illness could be around US\$ 3 trillion (based on US\$ 2019) - even if underestimated for the lack of some types of cost and of mental illness - and in 2010-2011 Australia spent A\$ 6.9 billion (7.7\% of all government health outlay) in mental health services by governments and health insurers. ${ }^{1}$ Studies also estimate that personal family costs and lost productivity for businesses and other non-government organisation costs, equal, or even surpass, the total government expenditures (Degney et al. 2012; Hilton et al. 2010; Jacobs et al. 2010).

The 2018 OECD report estimates as more than $4 \%$ of GDP (around $€ 600$ billion) the costs due to mental illness across Europe (OECD 2018), while Gustavsson et al. (2011) estimated it to be around $€ 800$ billion for the 2010, including Norway, Iceland and Switzerland to the 28 European countries.

A team of members from the World Economic Forum and the Harvard School of Public Health (Bloom et al. 2012) used different methods (although non comparable among each other) to estimate mental disorders costs: (1) direct and indirect costs by

\footnotetext{
${ }^{1}$ Department of Health and Ageing. National mental health report 2013, Canberra: Commonwealth of Australia, 2013.
} 
human capital approach (the standard cost-of-illness method), (2) impact on economic growth (macroeconomic simulation), and (3) value of statistical life (willingness to pay).

Each method has a different approach: personal versus social, private versus public, yearly costs versus multiple years' cumulative costs.

The human capital approach (1), as we anticipated earlier, considers personal costs such as medical costs, transportation, care, income losses (related also to education loss due to illness), and sometimes it can also add non-personal costs such as public health education campaigns and research.

The economic growth method (2), also called the value of lost output, considers how the investigated diseases diminish labour, capital and any other factors involved in the GDP formation at the country level, focusing on the illness related mortality rates impact on GDP.

The value of statistical life method (3) is based on the people's willingness to pay (a kind of trade off) to lessen the risk of disability or death connected with the analysed illness, therefore by attaching an economic value to health/life itself it goes beyond the practical impact on GDP alone. The quantification is done either by observed trade-offs (e.g. in the labour market the wage premium a worker is willing to receive to take a job with a high injury-death risk, or the extra amount of money an individual spends for healthier food) and hypothetical trade-offs (surveys asking people how much they would pay to elude a risk or how much they would ask to take that risk).

By method (1) the team (Bloom et al. 2012) estimated a world cost for mental illness of US\$ 2.5 trillion for the year 2010 alone, and US\$ 6 trillion for the year 2030 alone, two-thirds of which for indirect costs.

By method (2) they estimated a world cumulative GDP loss of US\$ 16.3 trillion (USA dollars 2010) due to mental health alone over 20 years (2011-2030).

By method (3) they estimated a world output loss of US\$ 8.5 trillion in 2010, and US\$ 16.1 trillion in 2030 .

Converted into US\$ for the year 2019, they resulted approximatively US\$ 19.2 trillion of GDP loss during the 20 years between 2011 and 2030; US\$ 7.1 trillion of human capital loss for the year 2030 alone; and US\$ 18.9 trillion the willingness to pay for the year 2030 alone.

All these estimates, even if already showing impressively high economic loss translations, are very likely underestimated (Whiteford et al. 2016).

\section{Urban-societal planning influence}

It seems clear from decades of a reasonable amount of mutually confirming independent research that urban life has unfavourable (often hidden) effects on our psyche, especially for those genetically susceptible and for those exposed to urban contexts during their juvenile years when the brain is still developing, whose causality has been proven by longitudinal and dose-response studies.

Most people may not be aware about this psychological damage as it might be that the harm does not reach a sufficient entity to become visible, and that would 
remain below a certain level implying a manifested invisibility. Yet, individuals might still suffer some kind of psychological uncomfortable feeling even without being able to define it, or, if so, to establish the direct link with their urban life.

If it is indeed true that it is not 'only' a small percentage of genetically susceptible urban dwellers targeted by statistically significantly higher psychosis risks, but a larger urban population, although with consistent variability in magnitude, we need to include this type of mental costs within any cost-benefit alike analysis.

Territorial and urban planners cannot ignore the negative consequences that cities and territories have on our psychological well-being and mental health when poorly planned, designed and managed (e.g. endless cementification, lack of daily natural contact, congestion, lack of sky view, crowding, visually and socially boring dormitory areas extended for hectares, ...). The same is valid for actions enabling us to change our socio-economic systems toward a more liveable scenario: just to cite an example, teleservices and teleworking (i.e. working remotely from home or wherever), a practice more and more in use $^{2}$ and even becoming law (since July 2015, first case in Europe and probably in the world) in the Netherlands if the worker wishes, would dramatically improve quality of life, free time, work efficiency and productivity, and enormously reduce congestion, daily car use, pollution, car parkstreet space, carbon emissions, and so on. Similar effects would be induced by flexible personalized working times (following personal biological circadian rhythmsessential for health and productivity - and private life schedules) and reduction of national daily working hours from, e.g. from 8 to $6 \mathrm{~h}$ : equivalent or probably even higher productivity thanks to more efficient use of working time, concentration, positive mood and an overall physical and psychologically healthier population.

Probably a substantial help will come from medical genetics, pharmaceutics and psychologic-psychiatric progress regarding non-modifiable risk factors such as age, sex and genetic make-up, and from urban-territorial planning and governance, politics and education regarding the modifiable risk factors such as environment (e.g. greener and less crowded-polluted cities) and life style (diet, sport, sleeping, hobbies, sociality, daily natural contact) part of it linked with the environment where one lives.

According to the large amount of empirical research evidence we saw, we can quite confidently say that urbanicity determines an approximately twofold increase in psychosis risk. Let's speculate that by planning better structural-infrastructural urban environments and forms (D'Acci 2020) and their socio-economic systems/life styles, (eliminating crowd-congestion, pollution, greenless, noise, crime, overwork, stress, over-pace...) of our current cities we are also able to entirely reduce their extra psychosis incidences and then levelling the urban psychosis rate to the rural one.

If we refer to the cost-of-illness method (human capital) which directly involves money actually spent in mental illness issues, US\$2.7 trillion $^{3}$ would be use for

\footnotetext{
${ }^{2}$ Especially after this Covid-19 pandemic.

${ }^{3} 0.604 * 2 \mathrm{x}+0.396 * \mathrm{x}=7.1$ trillion; $\mathrm{x}=7.1 /(0.604 * 2+0.396) \simeq 4.4 ; 0.604 * 2 * 4.4 \simeq 5.3$ trillion; half of them are $\simeq 2.7$ trillion.
} 
mental urban costs in 1 year alone (2030, when, according to UN 2019, a $60.4 \%$ of urban population is expected).

If we prefer to avoid forecasts so far away in time (2030) and refer our thoughts only to real data from the past, in 2010 the money actually spent for mental illness was US\$ 2.9 trillion worldwide (2019 dollars). An amount also in line with the 4\% of GDP costs for mental illness assessed by the 2018 OECD regarding Europe: in fact if we use this GDP percentage at the world level, the world GDP in 2010 was around (in current dollars) US\$ 66.037 trillion, ${ }^{4}$ whose $4 \%$ means US\$ 2.64 trillion, namely around US\$ 2.9 trillion in 2019 dollars. By following the previous reasoning about levelling the urban psychosis incidence to the non-urban one thanks to better urban planning and socio-economic life styles, the share of world urban population in 2010 was around $51.6 \%,{ }^{5}$ therefore US\$ 1 trillion ${ }^{6}$ could have been saved in urban mental illness costs in that year alone.

In 2018 the world urban population was around 55.3\% and the world GDP around US\$ 85.9 trillion $^{7}$ (current dollars), meaning roughly US\$ 87.4 trillion today, whose $4 \%$ is around US\$ 3.5 trillion which, following the same approximate reasoning (and assuming a similar percentage of GDP use) means that roughly US\$ 1.24 trillion $^{8}$ could have been not spent in mental illness due to urbanicity issues. If we assume a reduction of "only" $20 \%$ of urban mental illness rate, we would still save around 250 billion dollars yearly.

To put these trillions in context, the entire Apollo Space Program (1961-1973), including the 1969 walks on the Moon, still one of the major humanity achievements, costed only around US\$ 175 billion $^{9}$ (in 2019 dollars); almost 6 times less than what can be saved in only 1 year in mental illness due to urban life. An equivalent program but on Mars (sending nine crews), could cost around US\$ 1.5 trillion, ${ }^{10}$ while the Mars 2020 rover mission costs 'only' between 2 and 3 US\$ trillions. Another colossal human achievement, the 13 year Human Genome Project costed ‘just' US\$ 2.7 billion (1991 adjusted into 2018 dollars $^{11}$ ).

\section{Conclusions}

Cities are a potentially great place to live and achieve our life's goals and progress, both as individual and as a species; however, it has some mental costs for the most susceptible. By planning better cities, territories and socio-economic daily

\footnotetext{
${ }^{4}$ https://data.worldbank.org/indicator/ny.gdp.mktp.cd.

5 https://data.worldbank.org/indicator/sp.urb.totl.in.zs.

${ }^{6} 0.516 * 2 \mathrm{x}+0.484 * \mathrm{x}=2.9$ trillion; $\mathrm{x}=2.9 /(1.032+0.484) \simeq 1.9 ; 0.516 * 2 * 1.9 \simeq 2$ trillion; half of them are $\simeq 1$ trillion.

7 https://data.worldbank.org/indicator/NY.GDP.MKTP.CD.

$80.553 * 2 \mathrm{x}+0.447 * \mathrm{x}=3.5$ trillion; $\mathrm{x}=3.5 /(1.106+0.447) \simeq 2.25 ; 0.553 * 2 * 2.3 \simeq 2.544$ trillion; half of them are $\simeq 1.24$ trillion.

9 https://www.bbc.com/future/story/20190712-apollo-in-50-numbers-the-cost.

$10 \mathrm{https} / / /$ spacenews.com/op-ed-mars-for-only-1-5-trillion/.

11 https://www.genome.gov/human-genome-project/Completion-FAQ.
} 
life styles such as teleworking plus flexible working times, weekly working hour national reductions, greening cities and radically transforming the physical structures, forms and functioning of our current urban environments it would have an enormous potential economic impact environmentally, infrastructurally, but also psychologically speaking. From the academic literature we can say that the urban impact on mental health implies an approximately twofold increase in the rate of mental issues compared to the rural environment. Reports estimated a US\$ 2.9 trillion global expense for mental disorders in 2010 alone and forecasted to become as high as US\$ 7.1 trillion in the year 2030 alone. If we make a rather imaginative, although not that unrealistic, hypothesis to level the mental illness rate incidence of urban areas to these of the rural by better urban-societal planning, an astonishing amount of more than one trillion US dollars could be saved yearly: we could live happier, and send nine crews to Mars every year.

\section{References}

Adli M, Berger M, Brakemeier EL et al (2016) Neurourbanism-a joint methodological approach between urban planning and neurosciences. Die Psychiatr 13:70-78

Allardyce J, Boydell J, van Os J et al (2001) Comparison of the incidence of schizophrenia in rural Dumfries and Galloway and urban Camberwell. Br J Psychiatry 179:335-339

Batty M (2018) Inventing future cites. MIT press, Cambridge

Bedrosian TA, Nelson RJ (2013) Influence of the modern light environment on mood. Mol Psychiatry 18:751-757

Bentall RP, Fernyhough C (2008) Social predictors of psychotic experiences: specificity and psychological mechanisms. Schizophr Bull 34:1012-1020

Berry BJL, Okulicz-Kozaryn A (2009) Dissatisfaction with city life: a new look at some old questions. Cities 26:117-124

Berry BJL, Okulicz-Kozaryn A (2013) An urban-rural happiness gradient. Urban Geogr 32(6):871-883

Besteher B, Gaser C, Spalthoff R, Nenadić I (2017) Associations between urban upbringing and cortical thickness and gyrification. J Psychiatr Res 95:114-120

Bloom DE, Cafiero E, Jané-Llopis E, Abrahams-Gessel S, Bloom LR, Fathima S, Feigl AB, Gaziano TA, Mowafi M, O'Farrell D, Ozaltin E, Pandya A, Prettner K, Rosenberg L, Seligman B, Stein AZ, Weinstein C, Weiss J (2012) The global economic burden of noncommunicable diseases. PGDA working papers 8712 , program on the global demography of aging

Bowler DE, Buyung-Ali LM, Knight TM, Pullin AS (2010) A systematic review of evidence for the added benefits to health of exposure to natural environments. BMC Public Health 10:456

Brockmeyer S, D'Angiulli A (2016) How air pollution alters brain development: the role of neuroinflammation. Transl Neurosci 7(1):24-30

Calderón-Garcidueñas L, Cross JV, Franco-Lira M, Aragón-Flores M, Kavanaugh M, Torres-Jardón R, Chao C, Thompson C, Chang J, Zhu H, D'Angiulli A (2013) Brain immune interactions and air pollution: macrophage inhibitory factor (MIF), prion cellular protein (PrPC), Interleukin-6 (IL-6), interleukin 1 receptor antagonist (IL-1Ra), and interleukin-2 (IL-2) in cerebrospinal fluid and MIF in serum differentiate urban children exposed to severe vs. low air pollution. Front Neurosci 7:183

Caspi A, Sugden K, Moffitt TE, Taylor A, Craig IW, Harrington H, McClay J, Mill J, Martin J, Braithwaite A, Poulton R (2003) Influence of life stress on depression: moderation by a polymorphism in the 5-HTT gene. Science 301:386-389

Castillejos MC, Martín-Pérez C, Moreno-Küstner B (2018) A systematic review and meta-analysis of the incidence of psychotic disorders: the distribution of rates and the influence of gender, urbanicity, immigration and socio-economic level. Psychol Med 48(13):2101-2115

Christmas JJ (1973) Psychological stresses of urban living: new direction for mental health services in the inner city. J Natl Med Assoc 65:483-486 
Cohen PA (1982) Calculating people: the spread of numeracy in early America. University of Chicago Press, Chicago

Coid J, Zhang Y, Li T (2020) M132. Urbanicity and psychosis in a chinese undergraduate population: preliminary findings. Schizophr Bull 46(Suppl 1):S185-S186

Cooper JD, Ozcan S, Gardner RM, Rustogi N, Wicks S, van Rees GF, Leweke FM, Dalman C, Karlsson H, Bahn S (2017) Schizophrenia-risk and urban birth are associated with proteomic changes in neonatal dried blood spots. Transl Psychiatry 7(12):1290

D’Acci LS (2020) Preferring or needing cities? Psychology, utility and disutility of urban life (under review)

Degney J, Hopkins B, Hosie A, Lim S, Rajendren AV, Vogl G (2012) Counting the cost: the impact of young men's mental health on the Australian economy. Inspire Foundation and Ernst and Young, Canberra

Doran CM, Kinchin I (2017) A review of the economic impact of mental illness. Aust Health Rev 43:43-48

Easterlin RA, Angelescu L, Zweig JS (2011) The impact of modern economic growth on urban-rural differences in subjective well-being. World Dev 39(12):2187-2198

Eaton WW (1974) Residence, social class, and schizophrenia. J Health Soc Behav 15:289-299

Eaton WW, Mortensen PB, Frydenberg M (2000) Obstetric factors, urbanization and psychosis. Schizophr Res 43:117-123

Evans BE, Buil JM, Burk WJ, Cillessen AHN, van Lier PAC (2018) Urbanicity is associated with behavioral and emotional problems in elementary school-aged children. J Child Fam Stud 27(7):2193-2205

Evans BE, Huizink AC, Greaves-Lord K, Tulen JHM, Roelofs K, van der Ende J, Santana GL (2020) Urbanicity, biological stress system functioning and mental health in adolescents. PLoS ONE 15(3):e0228659

Faris REL, Dunham HW (1939) Mental disorders in urban areas. Chicago University Press, Chicago

Fassio O, Rollero C, De Piccoli N (2013) Health, quality of life and population density: a preliminary study on "contextualized" quality of life. Soc Indic Res 110:479-488

Fonken LK, Xu X, Weil ZM, Chen G, Sun Q, Rajagopalan S, Nelson RJ (2011) Air pollution impairs cognition, provokes depressive-like behaviors and alters hippocampal cytokine expression and morphology. Mol Psychiatry 16:987-995

Freeman D, Emsley R, Dunn G, Fowler D, Bebbington P, Kuipers E, Jolley S, Waller H, Hardy A, Garety P (2015) The stress of the street for patients with persecutory delusions: a test of the symptomatic and psychological effects of going outside into a busy urban area. Schizophr Bull 41:971-979

Frumkin H (2001) Beyond toxicity: human health and the natural environment. Am J Prev Med 20:234-240

Fuller RA, Irvine KN, Devine-Wright P, Warren PH, Gaston KJ (2007) Psychological benefits of greenspace increase with biodiversity. Biol Lett 3:390-394

Galea S, Uddin M, Koenen K (2011) The urban environment and mental disorders: epigenetic links. Epigenetics 6:400-404

Gibb S, Fergusson D, Horwood L (2010) Burden of psychiatric disorder in young adulthood and life outcomes at age 30. Br J Psychiatry 197(2):122-127

Gilbert A, Colley K, Roberts D (2016) Are rural residents happier? A quantitative analysis of subjective wellbeing in Scotland. J Rural Stud 44:37-45

Graziano MS, Cooke DF (2006) Parieto-frontal interactions, personal space, and defensive behavior. Neuropsychologia 44:2621-2635

Gruebner O, Rapp MA, Adli M, Kluge U, Galea S, Heinz A (2017) Cities and mental health. Dtsch Arztebl Int 114(8):121-127

Gustavsson A, Svensson M, Jacobi F, Allgulander C, Alonso J, Beghi E, Dodel R, Ekman M, Faravelli C, Fratiglioni L, Gannon B, Jones DH, Jennum P, Jordanova A, Jönsson L, Karampampa K, Knapp M, Kobelt G, Kurth T, Lieb R, Linde M, Ljungcrantz C, Maercker A, Melin B, Moscarelli M, Musayev A, Norwood F, Preisig M, Pugliatti M, Rehm J, Calvador-Carulla J, Schlehofer B, Simon R, Steinhausen H, Stovner LJ, Vallat J, Van den Bergh P, van Os J, Vos PE, Xu W, Wittchen H, Jönsson B, Olesen J (2011) Cost of disorders of the brain in Europe 2010. Eur Neuropsychopharmacol 22(3):237-238

Gwang-Won K, Gwang-Woo J, Tae-Hoon K, Han-Su B, Seok-Kyun O, Heoung-Keun K, Sam-Gyu L, Yoon Soo K, Jin-Kyu S (2010) Functional neuroanatomy associated with natural and urban scenic views in the human brain: 3.0T functional MR imaging. Korean J Radiol 11(5):507-513 
Haddad L, Schäfer A, Streit F, Lederbogen F, Grimm O, Wüst S, Deuschle M, Kirsch P, Tost H, MeyerLindenberg A (2015) Brain structure correlates of urban upbringing: an environmental risk factor for schizophrenia. Schizophr Bull 41(1):115-122

Haluza D, Schonbauer R, Cervinka R (2014) Green perspectives for public health: a narrative review on the physiological effects of experiencing outdoor nature. Int $\mathrm{J}$ Environ Res Public Health 11:5445-5461

Harrison GL, Fouskakis D, Rasmussen F et al (2003) Association between psychotic disorder and urban place of birth is not mediated by obstetric complications or childhood socioeconomic position: a cohort study. Psychol Med 33:723-731

Haukka J, Suvisaari J, Lonnqvist J (2001) Regional variation in the incidence of schizophrenia in Finland: a study of birth cohorts born from 1950 to 1969. Psychol Med 31:1045-1053

Heinz A, Deserno L, Reininghaus U (2013) Urbanicity, social adversity and psychosis. World Psychiatry 12:187-197

Helliwell JF, Shiplett H, Barrington-Leigh CP (2018) How happy are your neighbours? Variation in life satisfaction among 1200 Canadian neighbourhoods and communities. National Bureau of Economic Research NBER working paper no. 24592

Hilton M, Scuffham P, Vecchio N, Whiteford H (2010) Using the interaction of mental health symptoms and treatment status to estimate lost employee productivity. Aust N Z J Psychiatry 44(2):151-161

Jacobs P, Dewa C, Lesage A, Vasiliadis HM, Escober C, Mulvale G, Yim R (2010) The cost of mental health and substance abuse services in Canada: a report of the Mental Health Commission of Canada. Institute of Health Economics, Alberta

Joens-Matre RR, Welk GJ, Calabro MA, Russell DW, Nicklay E, Hensley LD (2008) Rural-urban differences in physical activity, physical fitness, and overweight prevalence of children. J Rural Health 24:49-54

Kelly BD, O’Callaghan E, Waddington JL, Feeney L, Browne S, Scully PJ, Clarke M, Quinn JF, McTigue O, Morgan MG, Kinsella A, Larkin C (2010) Schizophrenia and the city: a review of literature and prospective study of psychosis and urbanicity in Ireland. Schizophr Res 116:75-89

Kennedy DP, Glascher J, Tyszk JM, Adolphs R (2009) Personal space regulation by the human amygdala. Nat Neurosci 12:1226-1227

Kirkbride JB, Fearon P, Morgan C et al (2006) Heterogeneity in incidence rates of schizophrenia and other psychotic disorders: findings from the 3-center ÆSOP Study. Arch Gen Psychiatry $63: 250-258$

Kirkbride JB, Keyes KM, Susser E (2018) City living and psychotic disorders-implications of global heterogeneity for theory development. JAMA Psychiatry 75(12):1211-1212

Knox P, Pinch S (2006) Urban social geography: an introduction. Pearson Malaysia, Kuala Lumpur

Krabbendam L, van Os J (2005) Schizophrenia and urbanicity: a major environmental influence-conditional on genetic risk. Schizophr Bull 31:795-799

Krabbendam L, Hooker CI, Aleman A (2014) Neural effects of the social environment. Schizophr Bull 40(2):248-251

Krzywicka P, Byrka K (2017) Restorative qualities of and preference for natural and urban soundscapes. Front Psychol 8:1705

Laplagne P, Glover M, Shomos A (2007) Effects of health and education on labour force participation. Productivity Commission, Melbourne

Larson N, Ward DS, Neelon SB, Story M (2011) What role can child-care settings play in obesity prevention? A review of the evidence and call for research efforts. J Am Diet 111:1343-1362

Lawless NM, Lucas RE (2010) Predictors of regional well-being: a county level analysis. Soc Indic Res 101(3):341-357

Leach L, Butterworth P (2012) The effect of early onset common mental disorders on educational attainment in Australia. Psychiatry Res 199(1):51-57

Lecic-Tosevski D (2019) Is urban living good for mental health? Curr Opin Psychiatry 32(3):204-209

Lederbogen F, Kirsch P, Haddad L, Streit F, Tost H, Schuch P, Wüstv S, Pruessner JC, Rietschel M, Deuschle M, Meyer-Lindenberg A (2011) City living and urban upbringing affect neural social stress processing in humans. Nature 474:498-501

Levesque S, Surace MJ, McDonald J, Block ML (2011) Air pollution and the brain: subchronic diesel exhaust exposure causes neuroinflammation and elevates early markers of neurodegenerative disease. J Neuroinflamm 8:105

Lewis G, David A, Andreasson S et al (1992) Schizophrenia and city life. Lancet 340:137-140 
Maas J, Verheij RA, Groenewegen PP, de Vries S, Spreeuwenberg P (2006) Green space, urbanity, and health: how strong is the relation? J Epidemiol Community Health 60:587-592

Marcelis M, Navarro-Mateu F, Murray RM et al (1998) Urbanization and psychosis: a study of 19421978 birth cohorts in the Netherlands. Psychol Med 28:871-879

Marcelis M, Takei N, van Os J (1999) Urbanization and risk for schizophrenia: does the effect operate before or around the time of illness onset? Psychol Med 29:1197-1203

March D, Hatch SL, Morgan C, Kirkbride JB, Bresnahan M, Fearon P, Susser E (2008) Psychosis and place. Epidemiol Rev 30:84-100

McClung CA (2007) Circadian genes, rhythms and the biology of mood disorders. Pharmacol Ther 11:222-232

McClung CA (2011) Circadian rhythms and mood regulation: insights from pre-clinical models. Eur Neuropsychopharmacol 21(Suppl 4):S683-S693

McGrath J, Saha S, Welham J, El Saadi O, MacCauley C, Chant D (2004) A systematic review of the incidence of schizophrenia: the distribution of rates and the influence of sex, urbanicity, migrant status and methodology. BMC Med 2:13

Meyer-Lindenberg A (2010) From maps to mechanisms through neuroimaging of schizophrenia. Nature 468:194-202

Mortensen PB, Pedersen CB, Westergaard T et al (1999) Effects of family history and place and season of birth on the risk of schizophrenia. N Engl J Med 340:603-608

Mortensen PB, Pedersen MG, Pedersen CB (2010) Psychiatric family history and schizophrenia risk in Denmark: which mental disorders are relevant? Psychol Med 40:201-210

Newbury J, Arseneault L, Caspi A, Moffitt TE, Odgers CL, Fisher HL (2016) Why are children in urban neighborhoods at increased risk for psychotic symptoms? Findings from a UK longitudinal cohort study. Schizophr Bull 42(6):1372-1383

OECD (2018) Mental health performance framework. http://www.oecd.org/els/health-systems/menta 1-health.htm

Okulicz-Kozaryn A (2017) Unhappy metropolis (when American city is too big). Cities 61:144-155

Okulicz-Kozaryn A, Mazelis JM (2018) Urbanism and happiness: a test of Wirth's theory of urban life. Urban Stud 55(2):349-364

Park BJ, Tsunetsugu Y, Kasetani T, Kagawa T, Miyazaki Y (2010) The physiological effects of Shinrinyoku (taking in the forest atmosphere or forest bathing): evidence from field experiments in 24 forests across Japan. Environ Health Prev Med 15:18-26

Paykel E, Abbott R, Jenkins R, Brugha T, Meltzer H (2000) Urban-rural mental health differences in Great Britain: findings from the National Morbidity Survey. Psychol Med 30(2):269-280

Pedersen CB, Mortensen PB (2001a) Evidence of a dose-response relationship between urbanicity during upbringing and schizophrenia risk. Arch Gen Psychiatry 58:1039-1046

Pedersen CB, Mortensen PB (2001b) Family history, place and season of birth as risk factors for schizophrenia in Denmark: a replication and reanalysis. Br J Psychiatry 179:46-52

Pedersen CB, Mortensen PB (2006a) Are the cause(s) responsible for urban-rural differences in schizophrenia risk rooted in families or in individuals? Am J Epidemiol 163:971-978

Pedersen CB, Mortensen PB (2006b) Urbanization and traffic related exposures as risk factors for schizophrenia. BMC Psychiatry 6:1-7

Peen J, Dekker J, Schoevers RA, ten Have M, de Graaf R, Beekman AT (2007) Is the prevalence of psychiatric disorders associated with urbanization? Soc Psychiatry Psychiatr Epidemiol 42:984-989

Peen J, Schoevers RA, Beekman AT, Dekker J (2010) The current status of urban-rural differences in psychiatric disorders. Acta Psychiatr Scand 121:84-93

Peterson BS, Rauh VA, Bansal R, Hao X, Toth Z, Nati G, Walsh K, Miller RL, Arias F, Semanek D, Perera F (2015) Effects of prenatal exposure to air pollutants (polycyclic aromatic hydrocarbons) on the development of brain white matter, cognition, and behavior in later childhood. JAMA Psychiatry 72(6):531-540

Reed JL, D'Ambrosio E, Marenco S, Ursini G, Zheutlin AB, Blasi G, Spencer BE, Romano R, Hochheiser J, Reifman A, Sturm J, Berman KF, Bertolino A, Weinberger DR, Callicott JH (2018) Interaction of childhood urbanicity and variation in dopamine genes alters adult prefrontal function as measured by functional magnetic resonance imaging (fMRI). PLoS ONE 13(4):0195189

Sampson L, Ettman CK, Galea S (2020) Urbanization, urbanicity, and depression. Curr Opin Psychiatry 33(3):233-244

Sander W (2011) Location and happiness in the United States. Econ Lett 112:277-279 
Schelin E, Munk-Jorgensen P, Olesen A et al (2000) Regional differences in schizophrenia incidence in Denmark. Acta Psychiatr Scand 101:293-299

Schofield D, Kelly S, Shrestha R, Callander E, Percival R, Passey ME (2011) How depression and other mental health problems can affect future living standards of those out of the labour force. Aging Mental Health 15(5):654-662

Smetanin P, Stiff D, Briante C, Adair CE, Ahmad S, Khan M (2011) The life and economic impact of major mental illnesses in Canada: 2011 to 2041. Risk Analytica, on behalf of the Mental Health Commission of Canada; 2011, Toronto

Sørensen JFL (2014) Rural-urban differences in life satisfaction: evidence from the European Union. Reg Stud 48(9):1451-1466

Steinheuser V, Ackermann K, Schönfeld P, Schwabe L (2014) Stress and the city: impact of urban upbringing on the (re)activity of the hypothalamus-pituitary-adrenal axis. Psychosom Med 76(9):678-685

Stevens RG, Brainard GC, Blask DE, Lockley SW, Motta ME (2013) Adverse health effects of nighttime lighting: comments on American Medical Association policy statement. Am J Prev Med 45:343-346

Streit F, Haddad L, Paul T, Frank J, Schäfer A, Nikitopoulos J, Akdeniz C, Lederbogen F, Treutlein J, Witt S, Meyer-Lindenberg A, Rietschel M, Kirsch P, Wüst S (2014) A functional variant in the neuropeptide $S$ receptor 1 gene moderates the influence of urban upbringing on stress processing in the amygdala. Int J Biol Stress 17:352-361

Sundquist K, Frank G, Sundquist J (2004) Urbanisation and incidence of psychosis and depression. Br J Psychiatry 184:293-298

Tae-Hoon K, Gwang-Woo J, Han-Su B, Gwang-Won K, Thirunavukkarasu S, Heoung-Keun K, SeungWon L, Hyung-Joong K, Jin-Kyu S (2010) Human brain activation in response to visual stimulation with rural and urban scenery pictures: a functional magnetic resonance imaging study. Sci Total Environ 408(12):2600-2607

Tandon PS, Zhou C, Christakis DA (2012) Frequency of parent-supervised outdoor play of US preschool-aged children. Arch Pediatric Adolesc Med 166:707-712

Thornicroft G, Bisoffi G, De Salvia D et al (1993) Urban-rural differences in the associations between social deprivation and psychiatric service utilization in schizophrenia and all diagnoses: a caseregister study in Northern Italy. Psychol Med 23:487-496

Torrey EF, Mortensen PB, Pedersen CB et al (2001) Risk factors and confounders in the geographical clustering of schizophrenia. Schizophr Res 49:295-299

Tsunetsugu Y, Miyazaki Y (2005) Measurement of absolute hemoglobin concentrations of prefrontal region by near-infrared time-resolved spectroscopy: examples of experiments and prospects. J Physiol Anthropol Appl Hum Sci 24(4):469-472

UN (2019) World urbanization prospects: the 2018 revision. United Nations Department of Economic and Social Affairs, Population Division, New York, NY

Vaessen T, Hernaus D, Myin-Germeys I, van Amelsvoort T (2015) The dopaminergic response to acute stress in health and psychopathology: a systematic review. Neurosci Biobehav Rev $56: 241-251$

van Os J (2004) Does the urban environment cause psychosis? Br J Psychiatry 184:287-288

van Os J, Hanssen M, Bijl RV, Vollebergh W (2001) Prevalence of psychotic disorder and community level of psychotic symptoms. Arch Gen Psychiatry 58:663-668

van Os J, Pedersen CB, Mortensen PB (2004) Confirmation of synergy between urbanicity and familial liability in the causation of psychosis. Am J Psychiatry 161:2312-2314

van Os J, Kenis G, Rutten BPF (2010) The environment and schizophrenia. Nature 648:203-212

Vargas T, Conley RE, Mittal VA (2020) Chronic stress, structural exposures and neurobiological mechanisms: a stimulation, discrepancy and deprivation model of psychosis. In: Clow A, Smyth A (eds) Stress and brain health: in clinical conditions. International review of neurobiology, vol 152. Elsevier

Vassos E, Agerbo E, Mors O, Pedersen CB (2016) Urban-rural differences in incidence rates of psychiatric disorders in Denmark. Br J Psychiatry 208:435-440

Viganò F, Grossi E, Blessi GT (2019) Urban-rural dwellers' well-being determinants: when the city size matters. The case of Italy. City, Culture and Society. Available online 26 July 2019

Vigo D, Thornicroft G, Atun R (2016) Estimating the true global burden of mental illness. Lancet Psychiatry 3(2):171-178 
Vigo D, Kestel D, Pendakur K, Thornicroft G, Atun R (2019) Disease burden and government spending on mental, neurological, and substance use disorders, and self-harm: cross-sectional, ecological study of health system response in the Americas. Lancet Public Health 4(2):89-96

Wang JL (2004) Rural-urban differences in the prevalence of major depression and associated impairment. Soc Psychiatry Psychiatr Epidemiol 39:19

Weich S, Twigg L, Lewis G (2006) Rural/non-rural differences in rates of common mental disorders in Britain: prospective multilevel cohort study. Br J Psychiatry 188:51-57

White EA (1903) The geographical distribution of insanity in the United States. J Nerv Ment Dis 30:257-279

Whiteford HA, Ferrari AJ, Vos T (2016) Challenges to estimating the true global burden of mental disorders. Lancet Psychiatry 3(5):402-403

Wilker EH, Preis SR, Beiser AS, Wolf PA, Au R, Kloog I, Li W, Schwartz J, Koutrakis P, De Carli C, Seshadri S, Mittleman MA (2015) Long-term exposure to fine particulate matter, residential proximity to major roads and measures of brain structure. Stroke 46(5):1161-1166

Publisher's Note Springer Nature remains neutral with regard to jurisdictional claims in published maps and institutional affiliations. 